\title{
The Implementation of Audio-Visual Learning Media Based on Ispring Quizmaker on Thematic Learning Materials About Heroes to Improve Fourth Grade Students' Activities and Learning Outcomes
}

\author{
Dedy Agus Saputra \\ State University of Surabaya \\ Surabaya, Indonesia \\ dedyagussaputra@gmail.com
}

\begin{abstract}
The implementation of visual audio based on the ispring quiz-maker on thematic learning materials of struggle history is a mean to help improve the activities and learning outcomes of the students in learning. It was because the students are able to gain improvement in understanding the lesson that need to be understood. Therefore, the learning materials delivered by the teacher can be understood and wellremembered by the students. In addition, the importance of developing audio-visual learning media with Ispring Quizmaker is based on thematic learning on a material of the heroes' struggle since, in this material, the students find some difficulties.

The result of the research development of audiovisual learning media with Ispring Quiz-maker was based on thematic learning material of heroes struggle in order to fulfill the valid criterion with the result of the expert material test reaching the level of validity of $80 \%$, design experts which achieved $75 \%$, thematic learning experts which achieved $88 \%$, and field test results which achieved $75 \%$. The average grade of the class was 24,3 and post grade was 79,87 . In ttest, it was obtained that thing amount was 4.74 with a significance level of 0.05 with the degrees of freedom 29 was 1.697 so the $t$ count $4.74>\mathrm{t}$ table 1.697. The result of the hypothesis was accepted because $t$ count was bigger than the $t$ table. Therefore, it can be drawn the conclusion that there was a significant difference between students' understanding of class IV SDN Sedatigede II Kec.Sedati Kab.Sedati who experienced learning with audio-visual learning media with Ispring Quiz-maker based on thematic learning material about heroes' struggle.
\end{abstract}

Keywords-iMPLEMENTATION of visual audio; iSpring Quizmaker; Improving Learning Activity

\section{INTRODUCTION}

Developing knowledge and technology to improve learning outcomes, so teachers hope to use the tools or equipment effectively and efficiently in classroom learning. Technological developments require educators to use a variety of sophisticated learning media as a supporter of learning.

[1]Excess media can save time in learning activities and ease the task of teachers in teaching. The use of media other than as a tool in learning activities can also provide changes in students themselves.

The purpose of this development study was to reveal the feasibility level of the development of audio-visual learning media with iSpring Quizmaker 7.0.0 based on thematic learning about heroes' struggle in the fourth grade of SDN Sedatigede II. Furthermore, it aimed also at knowing the effectiveness of audio-visual learning media with iSpring Quizmaker 7.0.0 based on thematic lesson about heroes' struggle for the fourth-grade students of SDN Sedatigede II. The benefits gained from this research deals with having an alternative media or variance of media in conveying the thematic lessons about the struggle of the heroes.

\section{Research problems}

1. How is the feasibility level of developing an audio-visual language with iSpring Quizmaker 7.0.0 based on the material about heroes struggle in the fourth grade of SDN Sedatigede II?

2. How is the effectiveness of audio-visual learning media with iSpring Quizmaker 7.0.0 applied in thematic learning material about heroes struggle for fourth grade students of SDN Sedatigede II?

\section{Research purposes}

1. Knowing the feasibility level of developing audio-visual learning media with iSpring Quizmaker 7.0.0 based on the material about heroes struggle in the fourth grade of SDN Sedatigede II.

2. Knowing the effectiveness of audio-visual learning media with iSpring based Quizmaker 7.0.0. applied in thematic learning material about heroes struggle for fourth grade students of SDN Sedatigede II?

\section{Significance of the research}

This research was expected to support the concept of learning including the development of teaching methods dealing with knowledge, especially on the development of instructional 
media of audio-visual learning with iSpring Quizmaker 7.0.0 based on the thematic lesson about heroes in the fourth grade of Elementary school.

\section{Definition of Terms / Operations}

1. Ispring Quiz-maker is a software to convert ppt file (powerpoint) into an attractive flash so that the user/viewer can interact directly with the submitted materials.

2. A tool is a useful object that is used in a processor software program.

3. Publish is the term used to convert a file flash into an SWF or HTML format.

\section{LITERATURE REVIEW}

\section{A. Instructional Media}

The word media comes from the Latin word medius which literally means middle, intermediate, or introduction. Learning media is a tool that serves to convey learning messages[2]. [3] added that "media is everything that can deliver messages from sources in a planned manner in order to create a conducive learning environment where the recipient can make the learning process efficient and effective" [4]. Meanwhile, learning is the business of teachers to make students do learning activities. Thus, it can be concluded that the learning media is an important component in the teaching and learning activities as it plays a role as an intermediary that cannot be separated from the teaching and learning process for the achievement of educational goals and learning objectives in school.

\section{Ispring Quiz-maker}

Ispring Quiz-maker is one tool that converts presentation files compatible with the power point in the form of flash. Ispring Quiz-maker software is available in free (free) version. Ispring Quiz-maker can be easily integrated into Microsoft PowerPoint so the users do not need any special skills. Here are some of the features of Ispring Quiz-maker:

1. Ispring Quiz-maker works as an add-ins.

2. It is developed to support e-learning.

3. It is used to make a quiz with different types of questions.

\section{Definition of the hero}

A hero is a man who stands out for his courage and sacrifice themselves dealing with the defense of truth or a brave warrior. The word "hero" is derived from the Sanskrit phala-wan meaning that the person who produces a quality fruit (phala) for the nation, state, and religion. However, in the institutional context, the title of a "hero" is a formal award agreed by the components of the nation, which is subsequently endorsed by a political official side, the president.

\section{METHOD}

\section{A. Development style}

[5]The development design in this research used the ADDIE development model developed by Lee and Owens.
The reason for using this model was because the model was a procedural model, in which (1) it was a descriptive model, showing clear and careful steps to produce the product, (2) the development stages in this model were the same as the standard development stages, but the model was specially designed for multimedia learning. It is in line with the product to be developed [6].

\section{B. Data Analysis Technique}

[7]The data analysis technique used in this development used the triangulation technique. [8] states that, regarding the analysis of the data, "Qualitative data analysis is the process of searching and arranging systematically the data obtained by organizing them into categories, describing them into units, synthesizing, arranging them into patterns, choosing which one is important and that would be studied and be the source of drawing conclusions in order that it would be easily understood by self or others ".

\section{Validation}

[9] The learning media that had been created was validated by the validator. The results of development were in the form of data resulted from the validation done by the validator and small group testing in the form of student opinions related to the developed media. The revision of the developed media was done based on the validation results by the validator in the form of data numbers / scores and suggestions / criticism.

\section{RESULT AND DISCUSSION}

\section{Validation Results}

The learning media that had been created was then validated by the validator. The results of the development was in the form of data taken from the validation done by the validator and small group testing in the form of student opinions on developed media. The revision of the developed media was done based on the validation results by the validator in the form of data numbers / scores and suggestions / criticism.

\section{Data analysis}

Data Analysis on Material Validation Results

In the analysis of the material validation results, the questionnaires were analyzed using Likert scale involving 15 questions in order to obtain a score of at least 15, and a maximum of 75 , with the assessment criteria of $1=$ very bad, $2=$ not good, $3=$ medium, $4=$ good, $5=$ very good. The material assessment was done by Dra. Harlis, M.Si. From the validation, it was obtained a suggestion that the media still need adjustment dealing with the explanation of the picture. Moreover, from the results of the validation on the material analysis above, it was obtained a score of 60 and the percentage of the assessment of material validation of learning media was $60 / 75 \times 100 \%=80 \%$, therefore, it belonged to the good category.

60

$\overline{75}$. 


\section{CONCLUSION}

This learning media can be used as an alternative of means for learning in order to improve the creativity and motivation of students in the teaching and learning activities. The theme of the material was about heroes' struggle. Thematic learning media on the material can also be used as an independent learning for the students. As a comparison, the materials led to better learning media so that it can add interest and motivation of the students in order to be more active in the teaching and learning process.

\section{REFERENCES}

[1] R. E. Slavin, "Cooperative learning teori, riset dan praktik," Bandung Nusa Media, vol. 236, 2005.
[2] A. Arsyad, "Media pembelajaran." Jakarta: PT Raja Grafindo Persada, 2011.

[3] Y. Munadi, "Media Pembelajaran sebuah pendekatan baru." Jakarta: Gaung Persada Press, 2008.

[4] E. Ellsworth, Places of learning: Media, architecture, pedagogy. Routledge, 2005.

[5] J. W. Creswell, Educational research: Planning, conducting, and evaluating quantitative. Prentice Hall Upper Saddle River, NJ, 2002.

[6] H. P. Setyosari, Metode penelitian pendidikan \& pengembangan. Prenada Media, 2016.

[7] D. R. P. Sugiyono, "Metode Penelitian Administrasi Dilengkapi Dengan Metode R\&D," Revisi. Alf., 2009.

[8] Sugiyono, Metode penelitian pendidikan:(pendekatan kuantitatif, kualitatif dan $R \& D$ ). Alfabeta, 2008.

[9] N. Ariani and D. Haryanto, "Pembelajaran Multimedia di sekolah," Jakarta: Prestasi Pustaka, 2010. 